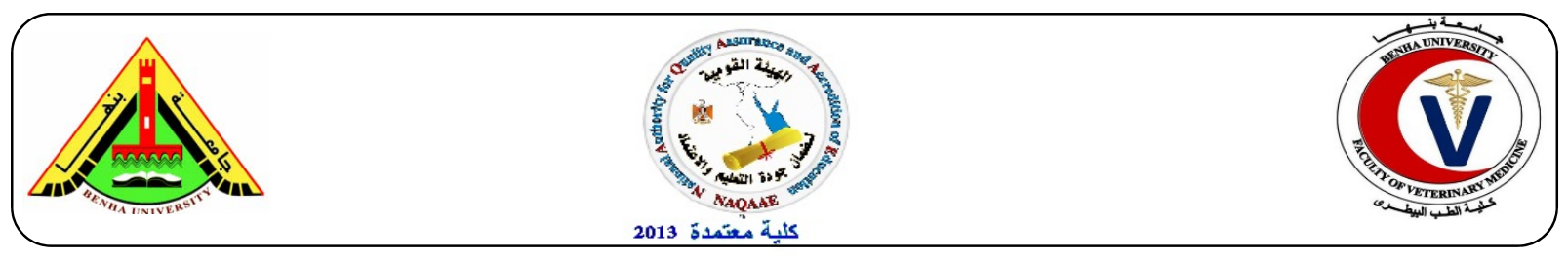

\title{
Biochemical effect of resveratrol on Lipids profile and hepatic oxidative stress in experimentally induced obesity in female rats
}

\author{
Samy Ali Hussein*, Afaf Desoky Abdel-Magid and Fareed Abd Elwahab Fareed \\ Biochemistry Department, Faculty of Vet. Med., Benha University, Egypt. \\ Corresponding author: E-mail: Samyaziza@yahoo.com
}

\section{A B S T R A C T}

This study was designed to evaluate the effect of prolonged intake of resveratrol on lipid metabolism, liver enzymes and L-malondialdehyde(L-MDA) in obesity -induced in female rats by feeding high fat diet. Ninety female albino rats were divided into six equal groups of 15 rats each. Group I: rats fed normal control diet all over the periods of experiment (for 12 weeks). Group II: rats fed the control normal diet and administered resveratrol orally ( $0.1 \mathrm{mg} / \mathrm{kg}$ b.wt., orally) for 6 weeks. Group III: rats received the control normal diet and received resveratrol once daily ( $0.5 \mathrm{mg} / \mathrm{kg}$ b.wt., orally) for 6 weeks. Group IV: rats fed high fat diet (HFD) and received no drugs all over the periods of experiment (for 12 weeks). Group V: rats received HFD and administered resveratrol $(0.1 \mathrm{mg} / \mathrm{kg}$ b.wt./day, orally) for 6 weeks. Group VI: rats fed HFD and administered resveratrol $(0.5 \mathrm{mg} / \mathrm{kg}$ b.wt./day, orally). Blood samples were collected from all rats at 2, 4 and 6 weeks from the onset of resveratrol administration for determination of serum total cholesterol(TC), Triacylglycerols (TAG), high density lipoprotein cholesterol (HDL-c), low density lipoprotein cholesterol (LDL-c), very low density lipoprotein cholesterol (VLDL-c), alanine aminotransferase (ALT), aspartate aminotransferase (AST), alkaline phosphatase (ALP), and erythrocyte L-malondialdehyde (L-MDA). The obtained results showed, significant elevation of serum TC, TAG, LDL-c, VLDL-c, ALP,AST, ALT, L-MDA in obese rats as compared to rats fed normal control diet. While administration of resveratrol to HFD-fed rats tended to improve hepatic oxidative stress and dyslipidemia through improving total cholesterol and triacylglycerols and liver markers enzyme activities. These results suggest that, resveratrol is effective in improving the obesity and its associated many important complications such as diabetes mellitus and coronary heart disease and liver disease.

Keywords: Resveratrol; obesity; Lipids profile; liver enzymes; L-malondialdehyde.

(http://www.bvmj.bu.edu.eg)

(BVMJ-32(1): 67-74, 2016)

\section{INTRODUCTION}

Obesity is a pathological condition in which excess body fat has accumulated to the extent that it may have an adverse effect on health, leading to reduced life expectancy or increased health problems. Obesity has reached the status of a global epidemic, with as many as 1.5 billion adults considered overweight and around 500 million obese. Lifestyle in combination with genetic predisposition is the major cause of obesity (Andreasen and Andersen, 2009). It is associated with many important complications such as diabetes, coronary heart disease and diseases of the gall bladder, liver and spleen (Abu-Abid et al., 2002). Obesity is associated with oxidative stress which may be due to extended postprandial hyperlipidemia and obese humans have increased levels of oxidative stress and this is ameliorated by diet restriction and weight loss (Dandona et al., 2001). Also, obesity is associated with increased activities of the secondary product of lipid peroxidation and weight loss has positive effects on oxidative stress and antioxidant activity (Uzun et al., 2004). Nowadays, there is an increased demand for using plants in therapy, the "back to nature" slogan, instead of using synthetic drugs which might have adverse effects and consequently might be more dangerous than the disease itself Mady et al. (2001). Resveratrol (3,5, 4'trihydroxystilbene), a naturally occurring polyphenol, has attracted considerable interest for its beneficial potentials for human health, which include anti-oxidant, anti-inflammatory, cardio protective, and anti-tumor activities (Amri et al., 2011). Resveratrol hypolipidemic effects were also shown by Cho et al. (2008).

Accordingly, the purpose of the present study was to investigate the effect of resveratrol against obesity- induced in female rats by feeding high fat 
diet. Through determination of serum lipids profile, liver markers enzymes and Lmalondialdehyde.

\section{MATERIALS AND METHODS}

\subsection{Experimental animals:}

Ninety white, female Albino Wister rats (8-10 weeks old age), weighing 165-225 gm. were used in the experimental investigation of this study. Rats were kept at constant environmental and nutritional conditions throughout the period of experiment. Animals were housed in separate metal cages. fresh and clean drinking water was supplied ad-libitum. All rats were acclimatized for minimum period of two weeks prior to the beginning of study.

\subsection{Ration and additives:}

The animals, were fed on constant ration through the course of the experiment in the form of concentrated diet composed of (7-10\% fat, $68-70 \%$ CHO, $18-20 \%$ protein, $1-2 \%$ vitamins and minerals; $210 \mathrm{kcal} / 100 \mathrm{gr} /$ day) normal control diet (NCD).

\subsection{Resveratrol}

Resveratrol, (3,5,4'-trihydroxystilbene) is a stilbenoid, a derivate of stilbene, with the molecular formula $\mathrm{C} 14 \mathrm{H} 12 \mathrm{O} 3$, molecular weight 228.2 , melting point $261-263{ }^{\circ} \mathrm{C}$, white powder with yellow casts and highly soluble in normal saline or $5 \%$ ethanol. It was manufactured by Sigma Chemical Co. (St. Louis, Mo, USA) and purchased from Schnelldorf, Germany through the Egyptian International Center for Import Cairo, Egypt. Resveratrol was freshly prepared (saline) and administered in orally at a dosage of $0.1 \mathrm{mg} / \mathrm{kg}$ body weight using stomach tube for group II, and the same dose were administrated for group $\mathrm{V}$ for 6 weeks, another dose $(0.5 \mathrm{mg} / \mathrm{kg}$ body weight $)$ was given for group III for 6 weeks and the same dose were administrated for group VI.

\subsection{Induction of obesity:}

The experimental induction of obesity in female rats was induced by feeding the rats on the prepared high fat diet (HFD) for Forty-five day before the beginning of the experiment according to the method of Altunkaynak (2005). Forty-five day, after obesity induction, treatment with resveratrol were given and continued for six weeks.

\subsection{Design of the experiment:}

Rats under study were randomly divided into six main equal groups, 15 rats each, placed in individual cages and classified as follows: Group I: (Normal control diet): Rats received normal control diet (NCD) all over the experimental periods. (for 12 weeks). Group П: (CND + Resveratrol): rats were maintained on CND and received Resveratrol $(0.1 \mathrm{mg} / \mathrm{kg}$ b.wt./day/orally) for 6 weeks. Group III: (CND + Resveratrol): rats were maintained on CND and received resveratrol $(0.5 \mathrm{mg} / \mathrm{kg} \mathrm{b.wt}$./day/orally) for 6 weeks. Group IV: (High fat diet): rats received high fat diet (HFD), served as obesity induced rats group, all over the periods of experiment. (For 12 weeks). Group V: (HFD + Resveratrol): rats were fed HFD and received resveratrol $(0.1 \mathrm{mg} / \mathrm{kg}$ b.wt./day/orally) for 6 weeks. Group VI: (HFD + Resveratrol): rats were fed HFD and received resveratrol $(0.5 \mathrm{mg} / \mathrm{kg}$ b.wt./day/orally) for 6 weeks.

\subsection{Sampling:}

Random blood samples were collected from all animal's groups (control and experimental groups) three times along the duration of experiment at 2, 4 and 6 weeks from the onset of rats exposed to lead and administrated with resveratrol. Blood samples were collected by ocular vein puncture from all animal groups three times along the duration of experiment and after overnight fasting. Part of blood collected in capped heparinized tubes and Erythrocytes were separated from blood plasma by centrifugation at 2500 r.p.m for 15 minutes. then kept in a deep freeze at $-20^{\circ} \mathrm{C}$ until used for subsequent biochemical analysis.

\subsection{Biochemical analysis:}

Serum total cholesterol, triacylglycerols, high density lipoprotein cholesterol (HDL-c), low density lipoprotein cholesterol (LDL-c), very low density lipoprotein cholesterol (VLDL-c), alanine aminotransferase (ALT), aspartate aminotransferase (AST), Alkaline phosphatase (ALP) and erythrocyte L-malondialdehyde (LMDA). were analyzed according to the methods described by Breuer (1996); Connerty et al. (1961); Friedewald et al. (1972); Friedman (1997); Matthews et al. (1985); National Cholesterol Education program (1995); NCEP expert panel (1988); Stein (1987); Tietz (1995), respectively.

\subsection{Statistical analysis:}

The obtained data were analyzed using the statistical package for social science, (SPSS, 13.0 software, 2009), for obtaining mean and standard deviation and error. The data were analyzed using one-way ANOVA to determine the statistical significance of differences among groups. Duncan's test was used for making a multiple comparison among the groups for testing the intergrouping homogeneity. 
Table (1): Effect of treatment with Resveratrol on serum Triacylglycerols, Total cholesterol and LDL-c concentrations in normal and obesity-induced in female rats $(\mathrm{mg} / \mathrm{dl})$.

\begin{tabular}{|c|c|c|c|c|c|c|c|c|c|}
\hline \multirow{2}{*}{$\begin{array}{l}\text { Parameters } \\
\text { Groups }\end{array}$} & \multicolumn{3}{|l|}{ triacylglycerol } & \multicolumn{3}{|c|}{ Total cholesterol } & \multicolumn{3}{|l|}{ LDL-c } \\
\hline & 2 weeks & 4 weeks & 6 weeks & 2 weeks & 4 weeks & 6weeks & 2 weeks & 4 weeks & 6 weeks \\
\hline Group I: & $108.89 \pm 1.91^{\mathrm{b}, \mathrm{c}}$ & $122.39 \pm 0.98^{\mathrm{c}}$ & $267.8 \pm 7.8^{\mathrm{b}}$ & $102.6 \pm 0.84^{\mathrm{c}}$ & $114.06 \pm 1.28^{\mathrm{c}}$ & $146.44 \pm 2.59^{c}$ & $39.95 \pm 0.57^{\mathrm{c}}$ & $38.67 \pm 0.40^{\mathrm{b}}$ & $40.84 \pm 2.69^{d}$ \\
\hline Group II: & $106.46 \pm 2.08^{\mathrm{b}, \mathrm{c}}$ & $112.65 \pm 1.32^{\mathrm{d}}$ & $209.62 \pm 4.59^{c}$ & $98.85 \pm 0.8^{\mathrm{c}, \mathrm{d}}$ & $111.88 \pm 1.66^{\mathrm{c}}$ & $122.72 \pm 2.1^{\mathrm{d}}$ & $33.58 \pm 0.51^{\mathrm{d}}$ & $36.86 \pm 0.16^{\mathrm{b}}$ & $31.54 \pm 6.63^{\mathrm{d}}$ \\
\hline Group III: & $103.45 \pm 1.97^{\mathrm{b}, \mathrm{c}}$ & $99.66 \pm 2.03^{\mathrm{e}}$ & $121.4 \pm 1.7^{\mathrm{e}}$ & $94.64 \pm .87^{\mathrm{d}}$ & $114.55 \pm 3.11^{\mathrm{c}}$ & $119.34 \pm 1.18^{\mathrm{d}}$ & $25.86 \pm 0.42^{\mathrm{e}}$ & $38.96 \pm 1.73^{b}$ & $30.78 \pm 1.15^{\mathrm{a}}$ \\
\hline Group IV & $155.36 \pm 2.54^{\mathrm{a}}$ & $175.85 \pm 2.49^{\mathrm{a}}$ & $311.46 \pm 3.63^{b}$ & $133.49 \pm 2.00^{\mathrm{a}}$ & $178.19 \pm 3.4^{\mathrm{a}}$ & $233.46 \pm 2.33^{b}$ & $60.8 \pm 1.18^{\mathrm{a}}$ & $86.64 \pm 15.26^{\mathrm{a}}$ & $154.41 \pm 9.73^{\mathrm{a}}$ \\
\hline Group V: & $109.75 \pm 4.87^{\mathrm{b}}$ & $150.27 \pm 1.87^{\mathrm{b}}$ & $165.89 \pm 2.55^{\mathrm{d}}$ & $118.86 \pm 2.09^{b}$ & $127.86 \pm 1.2^{\mathrm{b}}$ & $179.9 \pm 4.19^{b}$ & $53.93 \pm 1.67^{b}$ & $53.6 \pm 1.92^{\mathrm{b}}$ & $99.67 \pm 1.18^{\mathrm{b}}$ \\
\hline Group VI: & $100.46 \pm 1.29^{c}$ & $114.82 \pm 2.45^{\mathrm{d}}$ & $127.8 \pm 1.55^{\mathrm{e}}$ & $113.82 \pm 3.02^{b}$ & $117.29 \pm 4.59^{c}$ & $148.22 \pm 2.9^{c}$ & $50.33 \pm 4.38^{\mathrm{b}}$ & $46.28 \pm 2.57^{b}$ & $71.36 \pm 2.47^{\mathrm{c}}$ \\
\hline
\end{tabular}

Data are presented as $($ Mean \pm S.E). S.E $=$ Standard error. Mean values with different superscript letters in the same column are significantly different at $(p \leq 0.05)$.

Table (2): Effect of treatment with Resveratrol on serum HDL-c(mg/dl), VLDLc (mg/dl) and L-MDA( $\mu$ mol/l) concentrations in normal and obesity-induced in female rats.

\begin{tabular}{|c|c|c|c|c|c|c|c|c|c|}
\hline Parameters & HDL-c & & & VLDL-c & & & L-MDA & & \\
\hline Groups & 2 weeks & 4 weeks & 6 weeks & 2 weeks & 4 weeks & 6 weeks & 2 weeks & 4 weeks & 6 weeks \\
\hline Group I: & $40.94 \pm 0.89^{b}$ & $50.75 \pm 1.33^{\mathrm{a}, \mathrm{b}}$ & $55.23 \pm 1.93^{b}$ & $21.78 \pm 0.38^{b, c}$ & $24.48 \pm 0.19^{c}$ & $53.49 \pm 1.56^{\mathrm{a}}$ & $27.65 \pm 2.33^{d}$ & $31.39 \pm 2.41^{\mathrm{c}}$ & $46.17 \pm 1.73^{b}$ \\
\hline Group II: & $43.98 \pm 0.97^{\mathrm{a}, \mathrm{b}}$ & $52.82 \pm 1.76^{\mathrm{a}, \mathrm{b}}$ & $56.15 \pm 1.47^{b}$ & $21.29 \pm 0.42^{b, c}$ & $22.2 \pm 0.12^{\mathrm{d}}$ & $41.92 \pm 0.92^{\mathrm{b}}$ & $30.99 \pm 2.69^{c, d}$ & $34.33 \pm 2.9^{c}$ & $38.11 \pm 3.22^{\mathrm{c}}$ \\
\hline Group III: & $48.18 \pm 0.47^{\mathrm{a}}$ & $55.66 \pm 1.95^{\mathrm{a}}$ & $63.98 \pm 1.58^{\mathrm{a}}$ & $20.69 \pm 0.4^{b, c}$ & $19.93 \pm 0.41^{\mathrm{e}}$ & $24.28 \pm 0.33^{\mathrm{c}}$ & $33.51 \pm 0.7^{\mathrm{c}}$ & $33.56 \pm 0.86^{\mathrm{c}}$ & $30.3 \pm 0.6^{\mathrm{d}}$ \\
\hline Group IV : & $41.38 \pm 0.51^{\mathrm{b}}$ & $39.87 \pm 1.00^{\mathrm{d}}$ & $31.43 \pm 3.83^{\mathrm{d}}$ & $31.07 \pm 0.51^{\mathrm{a}}$ & $35.17 \pm 0.5^{\mathrm{a}}$ & $53.29 \pm 8.44^{\mathrm{a}}$ & $67.12 \pm 0.73^{\mathrm{a}}$ & $72.69 \pm 0.86^{\mathrm{a}}$ & $75.32 \pm 1.18^{\mathrm{a}}$ \\
\hline Group V: & $42.98 \pm 2.71^{\mathrm{a}, \mathrm{b}}$ & $44.21 \pm 2.75^{\mathrm{c}, \mathrm{d}}$ & $47.17 \pm 2.88^{c}$ & $21.95 \pm 0.97^{b}$ & $30.05 \pm 0.37^{b}$ & $33.18 \pm 0.51^{\mathrm{b}, \mathrm{c}}$ & $52.36 \pm 079^{\mathrm{b}}$ & $44.96 \pm 0.1^{\mathrm{b}}$ & $38.39 \pm 0.92^{\mathrm{c}}$ \\
\hline Group VI: & $43.12 \pm 2.56^{\mathrm{a}, \mathrm{b}}$ & $48.05 \pm 2.12^{b, c}$ & $51.22 \pm 1.43^{\mathrm{b}, \mathrm{c}}$ & $20.09 \pm 0.26^{\mathrm{c}}$ & $22.95 \pm 0.5^{\mathrm{d}}$ & $25.57 \pm 0.31^{\mathrm{c}}$ & $49.33 \pm 1.2^{\mathrm{b}}$ & $44.3 \pm 0.96^{\mathrm{b}}$ & $39.67 \pm 1.53^{c}$ \\
\hline
\end{tabular}

Data are presented as (Mean \pm S.E). S.E $=$ Standard error. Mean values with different superscript letters in the same column are significantly different at $(\mathrm{p} \leq 0.05)$. 
Table (3): Effect of treatment with Resveratrol on serum AST, ALT and ALP activities in normal and obesity-induced in female rats (U/L).

\begin{tabular}{|c|c|c|c|c|c|c|c|c|c|}
\hline Parameters & AST & & & ALT & & & ALP & & \\
\hline Groups & 2 weeks & 4 weeks & 6 weeks & 2 weeks & 4 weeks & 6 weeks & 2 weeks & 4 weeks & 6 weeks \\
\hline Group I & $197.22 \pm 2.45^{\mathrm{a}, \mathrm{b}}$ & $183.45 \pm 3.93^{\mathrm{a}}$ & $182.70 \pm 1.41^{\mathrm{b}}$ & $105.92 \pm 2.7^{\mathrm{a}, \mathrm{b}}$ & $76.51 \pm 2.07^{\mathrm{d}}$ & $105.54 \pm 2.62^{\mathrm{b}}$ & $137.77 \pm 4.18^{\mathrm{a}, \mathrm{b}}$ & $196.63 \pm 1.2^{\mathrm{a}, \mathrm{b}}$ & $266.44 \pm 9.63^{b}$ \\
\hline Group II & $188.10 \pm 3.31^{\mathrm{b}, \mathrm{c}}$ & $149.22 \pm 3.11^{\mathrm{b}}$ & $109.27 \pm 3.73^{\mathrm{d}}$ & $103.69 \pm 2.64^{\mathrm{a}, \mathrm{b}}$ & $71.65 \pm 1.85^{\mathrm{d}}$ & $103.55 \pm 2.77^{b}$ & $137.42 \pm 3.95^{\mathrm{a}, \mathrm{b}}$ & $186.96 \pm 2.13^{\mathrm{a}, \mathrm{b}, \mathrm{c}}$ & $255.15 \pm 3.43^{b}$ \\
\hline Group III & $169.17 \pm 3.45^{\mathrm{d}}$ & $111.42 \pm 4.48^{\mathrm{c}}$ & $82.45 \pm 1.49^{\mathrm{e}}$ & $88.05 \pm 2.17^{\mathrm{c}}$ & $68.44 \pm 2.07^{\mathrm{d}}$ & $103.55 \pm 2.54^{\mathrm{d}}$ & $118.08 \pm 13.13^{b}$ & $164.03 \pm 11.76^{\mathrm{b}, \mathrm{c}}$ & $174.04 \pm 10.07^{\mathrm{d}}$ \\
\hline Group IV & $199.67 \pm 1.06^{\mathrm{a}}$ & $186.73 \pm 8.94^{\mathrm{a}}$ & $200 \pm 4.49^{\mathrm{a}}$ & $116.62 \pm 2.79^{\mathrm{a}}$ & $129.93 \pm 3.57^{\mathrm{a}}$ & $116.18 \pm 2.6^{\mathrm{a}}$ & $156.2 \pm 8.61^{\mathrm{a}, \mathrm{b}}$ & $258.83 \pm 12.61^{\mathrm{a}}$ & $297.41 \pm 2.00^{\mathrm{a}}$ \\
\hline Group V & $183.40 \pm 6.06^{\mathrm{c}}$ & $176.36 \pm 8.91^{\mathrm{a}}$ & $124.90 \pm 9.17^{\mathrm{c}}$ & $93.84 \pm 8.85^{\mathrm{b}, \mathrm{c}}$ & $120.74 \pm 2.27^{\mathrm{b}}$ & $95.99 \pm 1.54^{\mathrm{c}}$ & $144.4 \pm 4.61^{\mathrm{a}, \mathrm{b}}$ & $117.67 \pm 52.44^{\mathrm{c}}$ & $252.04 \pm 6.7^{\mathrm{b}}$ \\
\hline Group VI & $134.61 \pm 2.66^{\mathrm{e}}$ & $131.30 \pm 3.32^{\mathrm{b}}$ & $102.60 \pm 2.10^{\mathrm{d}}$ & $85.31 \pm 4.41^{\mathrm{c}}$ & $86.06 \pm 3.6^{\mathrm{c}}$ & $88.7 \pm 1.95^{\mathrm{c}, \mathrm{d}}$ & $127.5 \pm 13.9^{\mathrm{a}, \mathrm{b}}$ & $154.24 \pm 5.64^{\mathrm{b}, \mathrm{c}}$ & $215.42 \pm 9.69^{c}$ \\
\hline
\end{tabular}

Data are presented as (Mean \pm S.E). S.E $=$ Standard error. Mean values with different superscript letters in the same column are significantly different at $p \leq 0.05$. 


\section{RESULTS}

The obtained data demonstrated in table $(1,2$ and 3) revealed a significant increase in serum levels of TC, TAG, LDL-c, VLDL-c, AIP, AST, ALT and L-MDA concentrations in obesity induced in rat's groups. Treatment of obese rats fed HFD with resveratrol ameliorate all of those parameters when compared to obese non-treated rats. However, serum HDL-c level was significantly decreased in obesity induced rat's groups. Treatment of HFD-fed rats marked increased in serum HDL-c level compared to HFDfed non-treated group.

Administration of resveratrol to rats fed normal control diet did not produce any significant changes in all serum biochemical parameters investigated in comparison to the values in normal control rats.

\section{DISCUSSION}

Obesity is characterized by a number of metabolic abnormalities which in all mas contribute to development of cardiovascular disorders (Vecchione et al., 2002). Great evidence suggesting obesity as an independent risk factor for a number of health problems, including liver and spleen disease (Chandrasekaran et al., 2012).

The present data demonstrated in table ( 1 and 2 ) revealed that, a significant increase in serum levels of TC, TAGs, VLDL-c, LDL-c and L-MDA. While, serum HDL-c level was significantly decreased in obesity induced in rat's groups. This result is consistent with those achieved by Cyrus et al. (2003) showed that, mice fed HFD had a significant increase in both plasma total cholesterol and triglycerides and LDL-C. That may lead to the development of abnormal lipid metabolism (Taboada et al., 2006). These results were in agreement with that of Lien and Horng (2001); Xu et al. (2011) who reported that plasma cholesterol, triacylglycerols, LDL-c, VLDL-c and phospholipids were increased in hypercholesterolemia animals. However, the level of HDL-C was significantly reduced (Al-Attar, 2010).

Additionally Brousseau et al. (2000) showed that hyperlipidemic diet caused a significant increase of the plasma triacylglycerols and cholesterol content in the liver, despite that diet produced a cessation of endogenous cholesterol synthesis. Visceral obesity is associated with impaired levels of triglycerides, increased very low-density lipoproteins (VLDL-C) and low - density lipoprotein cholesterol (LDL-C). Higher levels of VLDL-C diminish HDL-C cholesterol because of an exchange of core lipids, which is mediated by cholesterol ester transfer protein (Scott, 2003).

Similarly, Chalasani et al. (2004) reported that, a significant increase in serum L-MD concentrations. Hydroperoxides have toxic effects on cells both directly and through degradation to highly toxic hydroxyl radicals. They may also react with transition metals like iron or copper to form stable aldehydes such as malondialdehydes that will damage cell membranes. Peroxyl radicals can remove hydrogen from lipids, producing hydroperoxides that further propagate the freeradical pathway (Szabo, 2005).

Treatment of obese rats fed HFD with resveratrol significantly decreased serum TC, TAGs, VLDL-c, LDL-c and L-MDA concentrations with marked increased in serum HDL-c level compared to obese non-treated rats group. These results were in agreement with Beckerman and Koppenol (2014) who demonstrated that, the resveratrol prevents the oxidation of LDL "bad" cholesterol, and makes it more difficult for platelets to stick together and form the clots that can lead to a heart attack. Also, Day (2006) who revealed that, a significant decrease in serum in TC,TAG, LDL- C, VLDL-C concentrations mean while a significant increase HDL-C level was observed in resveratrol treated group. Moreover, Lixian et al. (2008) investigated effect of resveratrol on serum and liver lipid profile and antioxidant activity in hyperlipidemia rats showed that, the resveratrol hypolipidemic effect of resveratrol in treated rats as revealed by lower fat consumption and fat deposition. It was recorded serum lipid profile were not changed, the accumulation of abdominal white adipose tissues was markedly prevented in resveratrol diet-fed OLETF rats after 4 weeks of feeding, (Koji et al., 2013).

This result is consistent with those achieved by DiSilvestro et al. (2012) showed that, RES significantly inhibited lipid peroxidation in rats. Also, treatment with the resveratrol and vitamin $\mathrm{C}$ caused a significant $(p<0.01)$ decrease in the MDA in obese animals (Kamchouing et al., 1998) .

Moreover, Ramnath et al. (2007) showed that, Peroxidation in Cellular metabolic reactions generate small amounts of ROS, including hydroxyl radicals $(\bullet \mathrm{OH})$, superoxide anions $\left(\mathrm{O}_{2} \bullet-\right)$ and hydrogen peroxide $\left(\mathrm{H}_{2} \mathrm{O}_{2}\right)$. Under normal physiological conditions, ROS production is balanced by several cellular antioxidant mechanisms in order to avoid the harmful effects of these species. 
L- Malondialdehyde is a byproduct of the oxidative degradation of lipids in cell membranes, and the change in MDA concentration can be used as an index of oxidative cell damage. The significant decrease in MDA level by treatment of resveratrol (Akondi et al., 2011). Numerous investigations have reported that resveratrol inhibits effectively the lipid peroxidation of cellular membranes, the protein oxidation as well as the DNA damage due its ability to directly scavenge various free radicals, including superoxide radicals and peroxyl and hydroxyl radicals, (Leonard et al., 2003). In addition, the ability of the resveratrol is to exert protective effect against intoxication by reducing the MDA production that is indicative of its antioxidant activity, (Yousuf et al., 2009). Also Similarly, Resveratrol supplementation significantly reduced MDA in obese rats (Mehmet et al., 2016).

The obtained results presented in table (3) showed that, a significant increase in serum level AST, ALT and ALP activities in the obese rats compared to the control group. In obesity, fat accumulation in the cytoplasm of fatty hepatocytes caused a leakage of cytoplasmic ALT into the blood, (Guzzaloni et al., 2000). Moreover, the increment of the activities of AST, ALT, and ALP in plasma is mainly due to the leakage of a these enzymes from the liver cytosol into the blood stream (Navarro et al., 1993), which, indicated liver damage and disruption of normal liver function, (Shakoori et al., 1994). Serum AST and ALT values are higher in obese patients, probably because these persons commonly have fatty livers, (Salvaggio et al., 1991). Based on the fact that the more damage of the tissue cells is indicative to higher release of these enzymes in blood, (Rowland and Tozer, 1989), the increased serum AST and ALT along with reduction in their activities in liver, aorta and heart of atherogenic diet fed rats can be considered as a marker of atherogenic tissue injury. These results were in agreement with, Ali et al. (2006) who found that, alkaline phosphatase (ALP) has also been reported to increase in obesity. Additionally, agree with AlSultan (2008) who showed that serum level of alkaline phosphatase (ALP) in obese was significantly higher than non-obese subjects. Highcholesterol (HC) diet had an increasing effect on lipid peroxidation in plasma and tissue in rabbits.

The obtained results presented in table (3) showed that, Treatment of HFD-fed rats with resveratrol significantly decreased serum AST, ALT and ALP activities compared to obese nontreated control group. The difference is that ALT is found predominantly in the liver, with clinically negligible quantities found in the kidneys, heart, and skeletal muscle, while AST is found in the liver, heart (cardiac muscle), skeletal muscle, kidneys, brain, and red blood cells. Aspartate aminotransferase (AST) is commonly measured clinically as a part of diagnostic liver function tests, to determine liver health (Sushma et al., 2010). This result is consistent with those achieved by Ebyl et al. (2006) found that, RSV significantly decreased ALT and/or AST activity in animal models (mice or rats) with induced by obesity .Additionally, agree with Şehirli et al. (2008) showed that, RSV significantly decreased ALT and/or AST activity in animal models (mice or rats) with induced by obesity . Additionally, de la Lastra and Villegas (2005) stated anti-inflammatory effect of resveratrol on serum liver profile who recorded that, resveratrol was seen to decrease the liver lesions and transaminase activities caused obese in died mice. Also, Ibrahim et al. (2005) who recorded this decrease lipid profile and liver enzymes may be due to low activity of hydroxyl methyl glutaryle co-enzyme A in the liver, which responsible for cholesterol synthesis. It was recorded serum liver profile were not changed, the accumulation of abdominal white adipose tissues was markedly prevented in resveratrol diet-fed rats (Koji et al., 2013).

\section{CONCLUSION}

From the obtained results, it could be concluded that, administration of resveratrol to HFD-fed helped in controlling obesity tended to prevent hyperglycemia improve dyslipidemia and other changes relevant to complications disease mainly through improving lipid profile, liver enzymes and L-malondialdehyde (L-MDA).

\section{ACKNOWLEDGEMENT}

Special thanks for the Center of Excellence in Scientific Research (CESR) that follow Faculty of Veterinary Medicine, Benha University, especially Prof. Dr. Afaf Desoky Abdel -Magid the executive manager of the project. That Funded by Management Supporting Excellence (MSE) and Benha University.

\section{REFERENCES}

Abu-Abid, S., Szold, A., Klausner, J., 2002. Obesity and cancer. J Med 33, 73-86.

Akondi, B.R., Challa, S.R., Akula, A., 2011. Protective effects of rutin and naringin in testicular ischemia-reperfusion induced oxidative stress in rats. J Reprod Infertil 12, 209-214. 
Al-Attar, A.M., 2010. Hypolipidemic Effects of Coenzyme Q10 in Experimentally Induced Hypercholesterolemic Model in Female Rats. American Journal of Pharmacology and Toxicology 5, 14-23.

Al-Sultan, A.I., 2008. Assessment of the relationship of hepatic enzymes with obesity and insulin resistance in adults in saudi arabia. Sultan Qaboos Univ Med J 8, 185-192.

Ali, A.T., Paiker, J.E., Crowther, N.J., 2006. The relationship between anthropometry and serum concentrations of alkaline phosphatase isoenzymes, liver enzymes, albumin, and bilirubin. American Journal of Clinical Pathology 126, 437-442.

Altunkaynak, Z., 2005. Eeffects of high fat diet induced obesity on female rat livers. Eur J Gen Med 2, 100-109.

Amri, A., Chaumeil, T.C., Sfar, S., Charrueau, G., 2011. Administration of reaveratrol : what formulation solutions to biovaibility limitations? Journal of controlled release 158, 182-193.

Andreasen, C.H., Andersen, G., 2009. Geneenvironment interactions and obesity - Further aspects of genomewide association studies. Nutrition 25, 998-1003.

Beckerman, J.S., Koppenol, W.H., 2014. Nitric oxide, superoxide and peroxynitrite the good, the bad, and the ugly. Am. Physiol. Soci., 1424 - 1437.

Breuer, J., 1996. Report on the symposium - "Drug effects in clinical chemistry methods". European Journal of Clinical Chemistry and Clinical Biochemistry 34, 385-386.

Brousseau, M.E., Kauffman, R.D., Herderick, E.E., demosky, S.J., Evans, W., Marcovina, S., S-F, S., Brewer, H.B., Hoeg, J.M., 2000. LACT modulates atherogenic plasma lipoproteins and the extent of atherosclerosis only in the presence of normal LDL receptors in transgenic rabbits, atherosclerosis. Thrombosis and vascular disease boil. 300, 450 .

Chalasani, N., Deeg, M.A., Crabb, D.W., 2004. Systemic levels of lipid peroxidation and its metabolic and dietary correlates in patients with non alcoholic steatohepatitis. Am J Gastroenterol 99, 1497-1502.

Chandrasekaran, C.V., Vijayalakshmi, M.A., Prakash, K., Bansal, V.S., Meenakshi, J., Amit, A., 2012. Review article: herbal approach for obesity management. Am. J. Plant. Sci. 3, 1003-1014.

Cho, I.J., Ahn, J.Y., Kim, S., Choi, M.S., Ha, T.Y., 2008. Resveratrol attenuates the expression of HMG-CoA reductase mRNA in hamsters. Biochem Biophys Res Commun 367, 190-194.

Connerty, H.V., Briggs, A.R., Eaton, E.H., 1961. Determination of Serum, phospholipids, lipid phosphorous. In Practical Clinical Biochemistry, 4th ed. CBS Publishers, India.

Cyrus, T., Yao, Y., Rokach, J., Tang, L.X., Pratico, D., 2003. Vitamin E reduces progression of atherosclerosis in low-density lipoprotein receptor-deficient mice with established vascular lesions. Circulation 107, 521-523.

Dandona, P., Mohanty, P., Ghanim, H., Aljada, A., Browne, R., Hamouda, W., Prabhala, A., Afzal, A., Garg, R., 2001. The suppressive effect of dietary restriction and weight loss in the obese on the generation of reactive oxygen species by leukocytes, lipid peroxidation, and protein carbonylation. J Clin Endocrinol Metab 86, 355362.

Day, C.P., 2006. Genes or environment to determine alcoholic liver disease and non-alcoholic fatty liver disease. Liver Int 26, 1021-1028.

de la Lastra, C.A., Villegas, I., 2005. Resveratrol as an anti-inflamatoryand anti-aging agent: mechanisms an clinical implications. Mol Nutr Food Res 49, 405-430.

DiSilvestro, R.A., Joseph, E., Zhao, S., Bomser, J., 2012. Diverse effects of a low dose supplement of lipidated curcumin in healthy middle aged people. Nutr J 11, 79.

Ebyl, V., Kotyzkova, D., Koutensky, J., 2006. Comparative study of natural antioxidants curcumin, resveratrol and melatonin - in cadmium-induced oxidative damage in mice. Toxicology 225, 150-156.

Friedewald, W.T., Levy, R.I., Frederickson, D.S., 1972. Estimation of the concentration of low density lipoprotein cholesterol in plasma without use of the preparative ultracentrifuge. Clin Chem. 18, 499-502.

Friedman, Y., 1997. Effects of disease on clinical laboratory tests. AACC PRESS.

Guzzaloni, G., Grugni, G., Minocci, A., Moro, D., Morabito, F., 2000. Liver steatosis in juvenile obesity: correlations with lipid profile, hepatic biochemical parameters and glycemic and insulinemic responses to an oral glucose tolerance test. Int J Obes Relat Metab Disord 24, 772-776.

Ibrahim, A.A., ELsayed, E.M., Hafez, S.A., El-Zeini, H.M., Salah, F.A., 2005. The hypocholesterdaemic effect of milk youghurt and soy- youghurt containing bifido bacteria inrat fed on a cholestrol enriched diet. International Dairy Jouranl 15, 37-44.

Kamchouing, P., Sokeng, D.S., Moundipa, F.P., Watcho, P., Jatsa, B.H., Lontsi, D., 1998. Protective role of anacardium occidentale extract against streptozocin-induced in rats. $\mathrm{J}$ Ethnopharmacol 62, 55-99.

Koji, N., Tomoyuki, J., Shunichi, K., Teruyoshi, Y., 2013. Effect of dietary resveratrol on the metabolic profile of nutrients in obese OLETF rats. Lipids in Health and Disease 12:, 8.

Leonard, S.S., Xia, C., Jiang, B.H., Stinefelt, B., Klandorf, H., Harris, G.K., Shi, X., 2003. Resveratrol scavenges reactive oxygen species and effects radical-induced cellular responses. Biochem. Biophys. Res. Commun. 309, 1017-1026. 
Lien, T.F., Horng, Y.M., 2001. The effect of supplementary dietary L-carnitine on the growth performance, serum components, carcase traits and enzyme activities in relation to fatty acid beta-oxidation of broiler chickens. British Poultry Science 42, 92-95.

Lixian, Z., Xin, L., Zhengyu, J., 2008. Effect of Resveratrol on Serum and Liver Lipid Profile andAntioxidant Activity in Hyperlipidemia Rats.College of Food Science and Technology, Shandong Agricultural University, Taian, Shandong, 271018, China Asian-Aust. J. Anim. Sci. $21,890-895$.

Mady, N.I., Allam, A.F., Salem, A.I., 2001. Evaluation of the addition of Nigella sativa oiltriclabendazole therapy in the treatment of human fascioliasis. J. Egypt. Pharmacol. Exp. Ther 20, 807-827.

Matthews, D.R., Hosker, J.P., Rudenski, A.S., Naylor, B.A., Treacher, D.F., Turner, R.C., 1985. Homeostasis Model Assessment - Insulin Resistance and Beta-Cell Function from Fasting Plasma-Glucose and Insulin Concentrations in Man. Diabetologia 28, 412-419.

Mehmet, B.P., Halit Bugra, K., Gokhan, S., Fatma, A., 2016. Dietary Fructose Activates Insulin Signaling and Inflammation in Adipose Tissue: Modulatory Role of Resveratrol. Hindawi Publishing Corporation BioMed Research International

National Cholesterol Education program, 1995. Recommendation for Measurment of HighDensity Lipoprotein Cholesterol: Executive Summary. Clin Chem. 41, 1427-1433.

Navarro, M.C., Montilla, M.P., Martin, A., Jimenez, J., Utrilla, M.P., 1993. Free-Radical Scavenger and Antihepatotoxic Activity of RosmarinusTomentosus. Planta Medica 59, 312-314.

NCEP expert panel, 1988. (NCEP) Expert Panel on Detection, Evaluation, and Treatment of High Blood Cholesterol in Adults. circulation 148, 3669.

Ramnath, V., Rekha, P.S., Sujatha, K.S., 2007. Amelioration of Heat Stress Induced Disturbances of Antioxidant Defense System in Chicken by Brahma Rasayanae CAM Page 1 of 8.

Rowland, M., Tozer, T.N., 1989. In clinical pharmacokinetics: concepts and applications, 2nd ed. Lea Febiger, Philadelphia, USA.

Salvaggio, A., Periti, M., Miano, L., Tavanelli, M., Marzorati, D., 1991. Body mass index and liver enzyme activity in serum. Clin Chem 37, 720723.

Scott, C.L., 2003. Diagnosis, prevention, and intervention for the metabolic syndrome. Am J Cardiol 92, 35i-42i.

Şehirli, Ö., Tozan, A., Omurtag, G.Z., Cetinel, S., Contuk, G., Gedik, N., Şener, G., 2008. Protective effect of resveratrol against naphtalene-induced oxidative stress in mice. Ecotoxicol. Environ. Saf. 71, 301-308.
Shakoori, A.R., Butt, U., Riffat, R., Aziz, F., 1994. Hematological and biochemical effects of danitol administered for two months on the blood and liver of rabbits. Z. Angew. Zool. 80, 165-180.

Stein, E.A., 1987. Lipids, lipoproteins, and apolipoproteins.In:NW Tietz,ed Fundementals of clinical chemistry, 3rd ed. WB Saunders, Philadelphia.

Sushma, B., Kanwaljit, C., Praveen, R., 2010. Vitamin E Supplementation Modulates Endotoxininduced Liver Damage in a Rat Model. Am. J. Biomed. Sci. 2, 51-62.

Szabo, C., 2005. Roles of poly(ADP-ribose) polymerase activation in the pathogenesis of diabetes mellitus and its complications. Pharmacol Res $52,60-71$.

Taboada, M.C., Rodriguez, B., Millan, R., Miguez, I., 2006. Role of dietary L-arginine supplementation on serum parameters and intestinal enzyme activities in rats fed an excessfat diet. Biomedicine \& Pharmacotherapy 60,10 13.

Tietz, N.W., 1995. Clinical guide to laboratory tests, 3rd ed. WB saunders, philadelphia.

Uzun, H., Zengin, K., Taskin, M., Aydin, S., Simsek, G., Dariyerli, N., 2004. Changes in leptin, plasminogen activator factor and oxidative stress in morbidly obese patients following open and laparoscopic Swedish adjustable gastric banding. Obes Surg 14, 659-665.

Vecchione, C., Maffei, A., Colella, S., Aretini, A., Poulet, R., Frati, G., Gentile, M.T., Fratta, L., Trimarco, V., Trimarco, B., Lembo, G., 2002. Leptin effect on endothelial nitric oxide is mediated through Akt-endothelial nitric oxide synthase phosphorylation pathway. Diabetes 51, 168-173.

Xu, Q.Y., Anderson, D., Lurie-Beck, J., 2011. The relationship between abdominal obesity and depression in the general population: A systematic review and meta-analysis. Obesity Research \& Clinical Practice 5, E267-E278.

Yousuf, S., Atif, F., Ahmad, M., Hoda, N., Ishrat, T., Khan, B., Islam, F., 2009. Resveratrol exerts its neuroprotective effect by modulating mitochondrial dysfunctions and associated cell death during cerebral ischemia. Brain Res $1250,242-253$. 